\title{
Liquidity and Volatility of Stocks Moved from the Main Market to the Alternative Investment Market (AIM)
}

\author{
Mona Mortazian ${ }^{1}$ D
}

Accepted: 10 June 2021 / Published online: 10 July 2021

(C) The Authors 2021

\begin{abstract}
Companies moving from the Main market of London Stock Exchange to the AIM impair their information environment when entering the AIM; the information environment is measured by the stock's liquidity and volatility. The primary empirical finding is that movement from the Main Market to the AIM decreases the liquidity and volatility of stocks. After controlling for the effects of factors that are known to affect stock liquidity and for the change in company characteristics after the movement date in the multivariate analysis, it is found that moving to the AIM is associated with a significant increase in Amihud illiquidity and the bid-ask spread and with a decrease in stock return volatility. The documented effects of movement to the AIM are found to be sustained over a long period of time following the movement event. This therefore implies that moving from the Main Market to the AIM is not improving the companies' liquidity and volatility.
\end{abstract}

Keywords Alternative investment market (AIM) · Heckman two stage model · Liquidity · Multivariate analysis · Two-stage least squares (2SLS) · Volatility

\section{Introduction}

Firms generally present on a stock exchange to enhance their access to capital, prominence, reputation and liquidity (Bancel \& Mittoo, 2009; Mansaku et. al., 2017), with the critical objective of increasing the value of their stocks (Chouinard \& D'Souza, 2004; Mortazian et al., 2019). Joining reputable markets involves meeting strict requirements; therefore, markets such as the NASDAQ and the Alternative Investment Market (AIM) have been designed to provide accessibility to capital involving fewer regulations and costs than markets for example, the New York Stock Exchange (NYSE) and the Main Market of the London Stock Exchange (LSE). Gradually, most of the companies listed on the NASDAQ and AIM will become

Mona Mortazian

mona.mortazian@beds.ac.uk

1 University of Bedfordshire, University Square, Luton LU1 3JU, UK 
eligible to move to the NYSE and the Main Market after they have achieved growth (Dang et al., 2018; Mortazian et al., 2019). This movement enables them to fulfil better the aim of lowering their cost of capital, increasing their visibility and prestige and hence gaining more market value (Kedia \& Panchapagesan, 2011). The improvement in stock liquidity originates from the improvement in the information environment (Dabhane, 2018). Hence, a reduction of information asymmetry decreases the adverse selection factor of trading expenditures, resulting in improved liquidity and reduced transaction costs, especially the bid-ask spread (Dabhane, 2018; Glosten \& Harris, 1988; Kyle, 1985; Rodrigues \& Galdi, 2017). Therefore, the cost of capital decreases (Baiman \& Verrecchia, 1996; Diamond \& Verrechia, 1991; Gomes et al., 2019) and the firm value increases (Fang et al., 2009).

However, Campbell and Tabner (2011) show that the transactions between the AIM and the Main Market of the LSE include more companies that move from the Main Market to the AIM than conversely. They explain that more than twice as many firms move from the Main Market to the AIM as move in the reverse direction.

However, the literature shows that the impact of a change in the information environment on stocks' performances is sensitive to the proxy chosen, as the information environment itself is not simply quantifiable and empirically testable. Studies such as Leuz and Verrecchia (2000) and Blasco and Corredor (2017) state that stock liquidity and volatility are appropriate proxies when testing the quality of firms' information environment. They also reveal that the increase in stock liquidity and the decrease in stock volatility following cross listing to a more restricted market can be explained by the reduction in information asymmetry.

The existing literature concerning the change in stock liquidity and volatility resulting from companies' migration between markets is mixed. Some studies show that in markets with higher disclosure requirements, the trading costs are lower (Aouadi et al., 2018; Domowitz et al., 1998; Hamet, 2002; Hombach \& Sellhorn, 2018; Tse \& Devos, 2004) and the trading volume is higher (Babus \& Kondor, 2018; De Carvalho \& Pennacchi, 2012; Hamet, 2002; Tse \& Devos, 2004). Other studies show that there is no relationship between moving to another market with a different information level and trading expenditures (Noronha et al., 1996; Silva \& Chávez, 2008) or amount of trading volume (Berkman \& Nguyen, 2010; Domowitz et al., 1998). The literature relating to the volatility change between markets with different disclosure levels shows no significant change in volatility between the two types of market (Ang et al., 2013; Chipunza, \& McCullough, 2018; Howe \& Madura, 1990; Howe et al., 1993) or maximization in volatility in the higher-tier market because of the increase in trading activity (Bartram et al., 2012; Menkveld, 2008). Overall, the existing evidence regarding liquidity and volatility changes when firms move to another market with a different disclosure level is not conclusive.

This study underwrites to the literature by investigating the effect of shifting from the Main Market to the AIM on stocks' liquidity and volatility. More in detail, the key research question is: are companies that move from the Main Market to the AIM expected to have lower liquidity and higher volatility than companies that stay in the Main Market because migrations from the Main Market to the AIM deteriorate the stock information environment? 
In this study Sect. 2 debates the relevant literatures. Section 3 discusses about the data and methodology. Section 4 describes the empirical findings and finally Sect. 5 concludes the article.

\section{Literature Review}

\subsection{Liquidity}

Different studies examine the liquidity change after cross listing or moving from a lower-tier market to a higher-tier market by considering the change in trading volume and/or trading costs and find greater liquidity for these companies and conclude that liquidity, visibility and greater investor recognition are among the main reasons for moving to a market with more regulation. (Baker et al., 1999; Dodd \& Gilbert, 2016; Huang et al., 2013; Jain \& Kim, 2006; Papaioannou et al., 2009; Tandon \& Webb, 2001). However, despite all the illustrations mentioned about improving liquidity by moving to a more regulated market, there is some literature that shows that moving to a more regulated market may not always enhance liquidity (Amihud \& Mendelson, 1986; Kryzanowski \& Lazrak, 2009; Reinganum, 1990; Silva \& Chávez, 2008).

By deciding to move from the Main Market to the AIM market of the LSE, companies face lower entry requirements and are able to release less information, which is the first source that explains stocks' liquidity is expected to deteriorate after moving from the Main market to the AIM. Also, as stock liquidity is introduced as the capability to trade large quantities of the stock at a low cost, the two core scopes of liquidity are trading size and trading cost. Amihud illiquidity represents the trading activity dimension of liquidity and the bid-ask spread represents the trading cost dimension of liquidity. Therefore, it can be determined that a higher level of Amihud illiquidity and bid-ask spread would imply lower stock liquidity. Theoretically, Amihud (2002) and Lesmond (2005) illustrate the negative relationship of Amihud and trading activity, while Glosten and Milgrom (1985) and Kyle (1985) describe a positive relationship between the bid-ask spread and the level of information asymmetry. Wide-ranging empirical evidence approves that improved admission is associated with improved liquidity in terms of extents, trading sizes, depth and the adverse selection spread component (Healy et al., 1999; Heflin \& Shaw, 2000; Krishnamurti et al, 2005; Leuz \& Verrecchia, 2000; Welker, 1995).

The second source that explains the reduction in liquidity after moving to a less regulated market is the relationship between trading volume and information asymmetry. Studies such as Kyle (1985) and Noronha et al (1996) and more recent studies such as Collin-Dufresne and Fos (2016) all illustrate that information arrival maximize the trading size and empirically approve the increase in informed trading after cross listing. Thus, it can be concluded that deterioration in the information environment can be a result of the decrease in the number of market contestants who have the motivation to generate stock-specific information to profit from informed trading. 
Furthermore, Stoll (1978, 2001) and Amihud and Mendelson (1995) show hypothetically that enhanced competition forces market makers to decrease the spread. Therefore, the third source of the reduction in liquidity creates from the lower level of inter-market competition in the AIM than in the Main Market. Finally, as Merton (1987) mentions, a more liquid trading environment after listing in a more regulated market could be likely as a result of increased stock visibility and investor acknowledgment, and a less liquid trading environment after moving from the Main Market to the AIM could be likely as a result of reduced stock visibility and investor acknowledgment. Therefore, the first hypothesis is:

H1 Moving from the Main Market to the AIM reduces the liquidity of a stock.

\subsection{Volatility}

A group of studies suggests that higher information quality signals lower market risk and hence lower volatility (Barry \& Brown, 1986; Brockman \& Yan, 2009; Lambert et al., 2007; Wang, 1993). Another group of studies mentions that the higher trading volume results in higher volatility (Chan \& Fong, 2000; Hatrick, et al., 2011; Jones et al., 1994; Kim et al., 2005) therefore, the lower trading volume that is evident after moving to a less regulated market should be associated with lower volatility. A lower trading volume after movement is expected to be due to the decrease in the number of investors after moving to a lower-tier market and the smaller quantity of information that is released to the market. Less information results in less trading, potentially because of diverse clarifications of public data by investors (Bamber et al., 1999). Thus, academic forecasts on the effect of shifting from a high-regulation market to a low-regulation market on stock risk are unclear and need support with empirical evidence.

Studies such as Barclay et al. (1990), Eleswarapu and Venkataraman (2006) that employ daily data explain that stock return volatility increases after appearing in a more regulated market because the trading volume is greater in the destination market. Foucault and Frésard (2012) argue that a cross-listing to a more regulated market, enhance investors' reliance on stock prices as it makes them more informative to them, which result to lower volatility.

The second group of studies uses intraday data to analyse the change in volatility after listing to another market. Chan et al. (1996) explain that stocks that cross list from different countries to the US face greater volatility and more trading activities than US stocks that cross list to other markets; they illustrate that this change is more significant in early mornings. They also mention the market response to public information gathered in the foreign markets overnight as one of the possible explanations for this change. Lowengrub and Melvin (2002) explain that the intradaily volatility is generally described by a U-shape, which shows that the volatility is high near the morning opening and near the afternoon closing. However, different studies propose that the intraday model of information asymmetry is neither U-shaped nor the reverse. Garvey and $\mathrm{Wu}$ (2009) mention that the execution speed and execution cost determine intraday time-dependent models and that these models originate 
from changes in the level of informed trading. Heston et al. (2010) show that volume, order imbalance, volatility, bid-ask spreads and stock returns play a role in particular patterns at half-hour intervals that are exact multiples of a trading day.

Overall, the empirical evidence on the impact of moving from a less regulated market to a more regulated market or cross listing on stock return volatility is mixed. However, there is a mutual component in most of the empirical evidence: the change in volatility after cross listing is positively in relation to the change in trading volume after cross listing.

A smaller amount of information released by companies results in greater information asymmetry, which is a source of risk and higher volatility. As mentioned by different literature, such as Brockman and Yan (2009), the higher volatility is due to the higher level of uncertainty about the stock's future cash flows. In addition, Lang and Lundholm (1993) believe that the higher volatility that results from greater information asymmetry could be a consequence of the stock price reaction to new information. Moreover, studies such as De Long et al. (1990), Campbell and Kyle (1993) Kim et al. (2005) and Hatrick et al. (2011) introduce noise trading as another reason for greater stock volatility when the information asymmetry increases. These studies explain that when active noise trading increases, the stock price informativeness decreases, resulting in increased uncertainty about the stock fundamentals for uninformed traders and subsequently increased risk. Hence, since moving from the Main Market to the AIM is associated with a lower level of information disclosure due to lower listing requirements, it should increase the stock risk and stock return volatility. Therefore, the second hypothesis is:

H2 Stock movement from the Main Market to the AIM increases the stock return volatility.

\section{Methodology}

In order to analyse the impact of moving from the Main Market to the AIM on stocks' liquidity and volatility, cross-sectional analysis, evolution of stock liquidity and volatility and time-series framework are applied.

\subsection{Cross-Sectional Analysis}

In the cross-sectional analysis, the liquidity and volatility of companies that moved from the Main Market to the AIM are compared with those of companies that remained in the Main Market. The deterioration in liquidity and volatility after movement from the Main Market to the AIM are potentially not a direct outcome of movement, but rather the replication of the fact that stocks with lower liquidity and higher volatility are more likely to move from the Main Market to the AIM. Therefore, there is a potential endogeneity problem in the valuation of the relationship between moving from the Main Market to the AIM and stock liquidity and volatility. Doidge et al. (2004) highlight, it is crucial to control for the self-selection bias in the 
regression analysis. Doidge et al. (2004) and Fernandes and Ferreira (2008) both use Heckman's (1979) two-stage estimation and two-stage least squares (2SLS) ${ }^{1}$ models, which are used in this study to govern for possible endogeneity.

The first stage of the Heckman estimation tests the likelihood of movement from the Main Market to the AIM by considering the companies' characteristics.

$$
\text { Probability }\left(\mathrm{MS}_{i, t}\right)=f\left(\omega M_{i, t}\right)
$$

where Probability is the likelihood of stocks' movement from the Main Market to the AIM, $M_{i, t}$ is the movement dummy variable that equals one if stock i is moved from the Main Market to the AIM in month $\mathrm{t}$ and zero otherwise; $M_{i, t}$ are the possible causes of movement status. Thus as shown in Eq. (1), probability of movement from Main to AIM is a function $(f)$ of companies' characteristics.

The company characteristics considered in the probit model can have an impact on stocks' information environment and, therefore, on stock liquidity and volatility. The first factor considered in this study is company size, which is measured by stock market capitalization. To calculate liquidity and volatility and the regression analysis, the monthly stock market capitalization (stock market capitalization at the end of the month) is used. The second factor that is considered to have an impact on the information environment is international accounting standards (IAS), which is the dummy variable that represents the acceptance of IAS accounting practices. The IAS variable changes over time and shows whether any changes have been applied to the company's accounting standards. The last variable that exerts an impact on stocks' liquidity and volatility by affecting the information environment after a move from the Main Market to the AIM is the level of trading activity, and this is measured by the stock's total trading volume.

Moreover, many different studies, such those by as Roll (1984), Atkins and Dyl (1997), Glosten and Harris (1988), Stoll (2001), Menyah and Paudyal (2000) and Gregoriou et al. (2005), mention that, apart from the company size, stocks' liquidity and volatility are affected by the level of trading activity. In this study, to control for this, the stock turnover ratio is included in the return volatility regressions. To control for the company risk dimension, leverage as measured by total liabilities to total assets is included in the regressions of the liquidity volatility measures. The maximum likelihood coefficient, which is produced by the probit model, is used to estimate the inverse Mills ratio.

$$
\begin{aligned}
& \text { for } \mathrm{MS}_{i, t}=1, \lambda_{i, t}=\varphi\left(\omega M_{i, t}\right) / \Phi\left(\omega M_{i, t}\right) \\
& \text { for } \mathrm{MS}_{i, t}=0, \lambda_{i, t}=-\varphi\left(\omega M_{i, t}\right) /\left[1-\Phi\left(\omega M_{i, t}\right)\right]
\end{aligned}
$$

where $M_{i, t}$ is the movement dummy variable, which equals one if stock $i$ moves from the Main Market to the AIM in month $t$ and zero if not; $\lambda_{i, t}$ is the opposite Mills ratio; $\varphi$ is the normal probability distribution function; and $\Phi$ is the normal

\footnotetext{
1 In addition, both Doidge et al. (2004) and Fernandes and Ferreira (2008) apply a random-effect model to compare its result with the result of models considering self-selection bias. Therefore, random-effect regression is run in this study as well.
} 
cumulative distribution function. Therefore, Eq. 2 is to calculate the inverse Mills ratio, which is an evaluation of the non-selection hazard and is calculated to estimate the chance of a stock moving from the Main Market to the AIM.

In the second stage of the Heckman estimation, the link between the measures of liquidity and volatility and the movement status and other stock characteristics are estimated using a multivariate framework. Multivariate regression in this study includes the estimated inverse Mills ratio to consider the self-selection bias and achieve consistent parameter estimates.

Therefore, the main model specification is:

$$
\text { Liquidity/Volatility Measure } i, t=\alpha+\beta D_{i, t}+\Sigma \theta M_{i, t}+\gamma \lambda_{i, t}+\varepsilon_{i, t}
$$

where $D_{i, t}$ is a dummy variable that replicates the movement status of stock $i$ in month $t ; M_{i, t}$ are control variables; and $\lambda_{i, t}$ is the opposite Mills ratio.

Moreover, this study includes the test results of the two-stage least-squares (2SLS) model. In the two-stage least squares (2SLS) model, the same exogenous variables as in the probit model is used as instrumental variables.

\subsection{Evolution of Stock Liquidity and Volatility}

As previously discussed, there is an endogeneity problem concerning the possibility of movement of less liquid and riskier stocks from the Main Market to the AIM. Thus this study considers the evolution of the stock liquidity and volatility of moved stocks before and after movement ${ }^{2}$.

For the purpose of illustrating the dynamics, the liquidity and volatility of stocks that moved from the Main Market to the AIM are calculated in each year $(-4,-3$, $-2,-1,+1,+2,+3,+4)$; first, they are compared with the stock liquidity and volatility in year before movement, and second, they are compared with the liquidity and volatility of stocks that stayed in the Main Market. In addition, the evolution of stock liquidity and volatility is estimated by applying a multivariate regression analysis framework. Furthermore, in the cross-sectional regression, instead of a dummy variable to show the movement status, a series of dummy variables that indicate the number of years around the movement $(-4,-3,-2,-1,+1,+2,+3,+4)$ is used in the regression. Therefore, by controlling the other factors, the coefficient estimates for each year's dummy determine the growth of stock liquidity and volatility before movement, during the year of movement and after movement.

\footnotetext{
2 This approach is similar to that of Gozzi et al. (2008), who evaluate the change in Tobin's Q around cross listing, and Hail and Leuz (2009), who estimate the reduction in the cost of capital after cross listing.
} 


\subsection{Time-Series Framework}

This study considers the 48-month period before movement as the base period for the estimation of the base variables ${ }^{3}$. The base measures of stock liquidity and volatility are calculated for each stock as the averages of all these measures over the time when the stock had not moved from the Main Market to the AIM. In this study, daily data are used to calculate all the liquidity and volatility measures for each month. Table 1 reviews the liquidity and volatility measures estimated in this study.

In the next step, to apply univariate analysis, the ratios of the liquidity and volatility measures along with all explanatory and control variables are calculated. Therefore, the ratios are calculated as a variable in month $t$ to the base variable, which is the average value of the variable over the period when the stock was listed on the Main Market:

$$
\text { (Liquidity } \left._{\mathrm{it}} \text { or Volatility }_{\mathrm{it}} / \text { Liquidity }_{\mathrm{bit}} \text { or Volatility }_{\mathrm{bit}}\right)=\alpha+\omega D_{i, t}+\Sigma \theta\left(\mathrm{EC}_{i, t} / \mathrm{EC}_{i, \mathrm{base}}\right)+\varepsilon_{i, t}
$$

where Liquidity it $_{\text {or Volatility }}$ it is defined as the liquidity or volatility measure of stock $i$ in month $t$; Liquidity ${ }_{\text {bit }}$ or Volatility $_{\text {bit }}$ is the base liquidity or volatility measure of stock $\mathrm{i} ; D_{i, t}$ is a dummy variable that shows the movement status of stock $i$ in month $t ; E C_{i, t}$ are different stock characteristics, including the descriptive and control variables, of stock $i$ in month $t$; and $E C_{i, \text { base }}$ are the base stock characteristics of stock $i$. By using these model specifications, it is possible to assess whether the variation in stock liquidity and volatility is affected by the variation in the movement status or by the variations in the stock characteristics after movement.

\section{Findings and Results}

The sample includes two groups of companies: the first group consists of companies that moved from the Main Market to the AIM; and the second group includes companies that remained listed on the Main Market. Each company in the first group is matched with one company in the second group. The matching process is similar to Errunza and Miller (2000); however, following Baker et al. (2002) the industry component is added. The differences in variable means between the two groups of companies that moved from the Main Market to the AIM (MAIN2AIM) and their matched companies that stayed in the Main Market (MATCH) are depicted in Table 2. Based on the t-test applied, it can be concluded that the mean of liquidity measures of MAIN2AIM stocks are significantly different from that of the MATCH stocks. Furthermore, Panel A of Table 2 depicts the significant difference in the volatility measures' mean between the two groups of MAIN2AIM and MATCH. As expected, the volatility ratio of the MAIN2AIM firms is significantly higher than that of the MATCH firms. In contrast, comparing the return volatility and high-low

\footnotetext{
3 As applied by Lowengrub and Melvin (2002), controlling the liquidity and volatility of the moved stocks around their movement is another method for considering self-selection bias.
} 


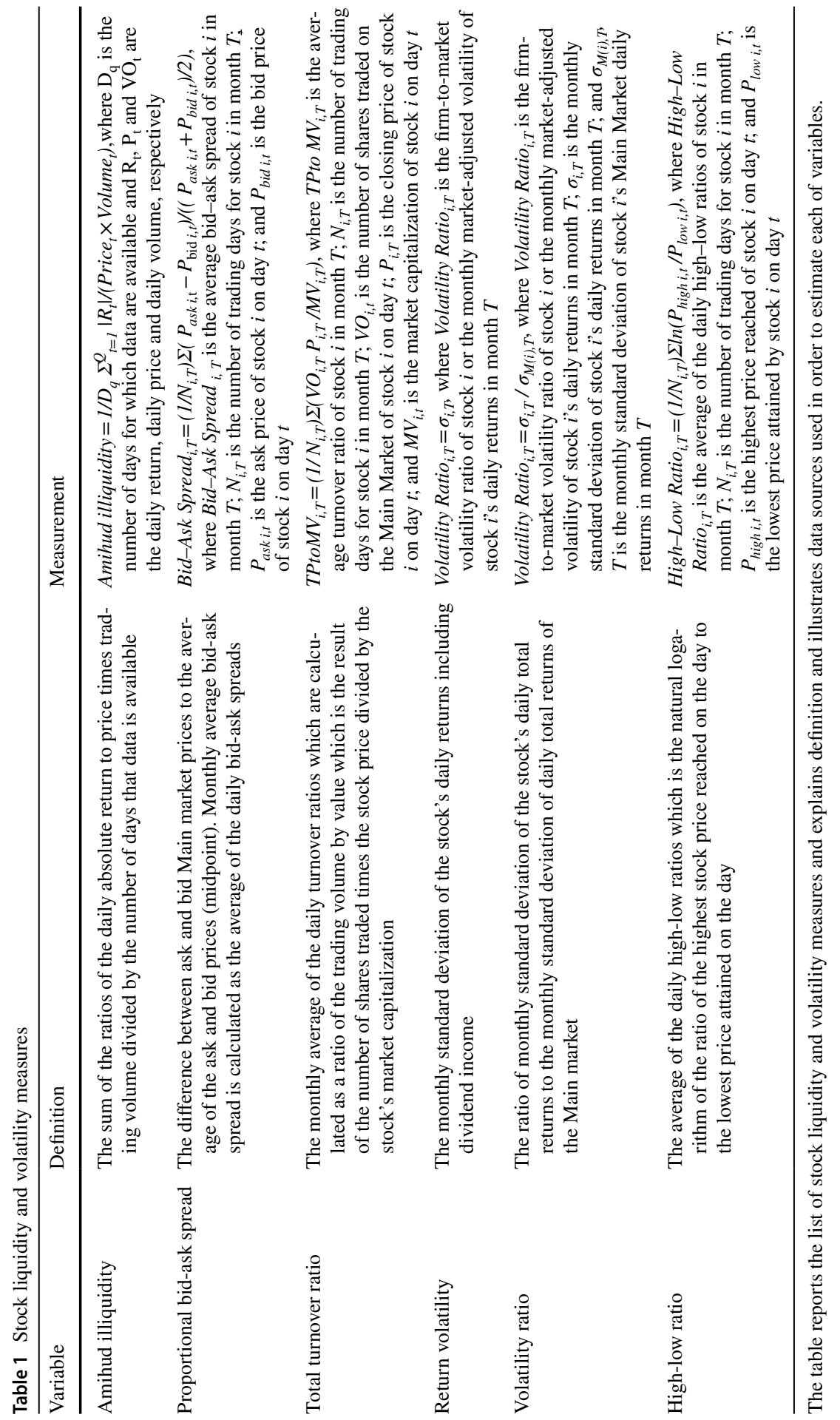




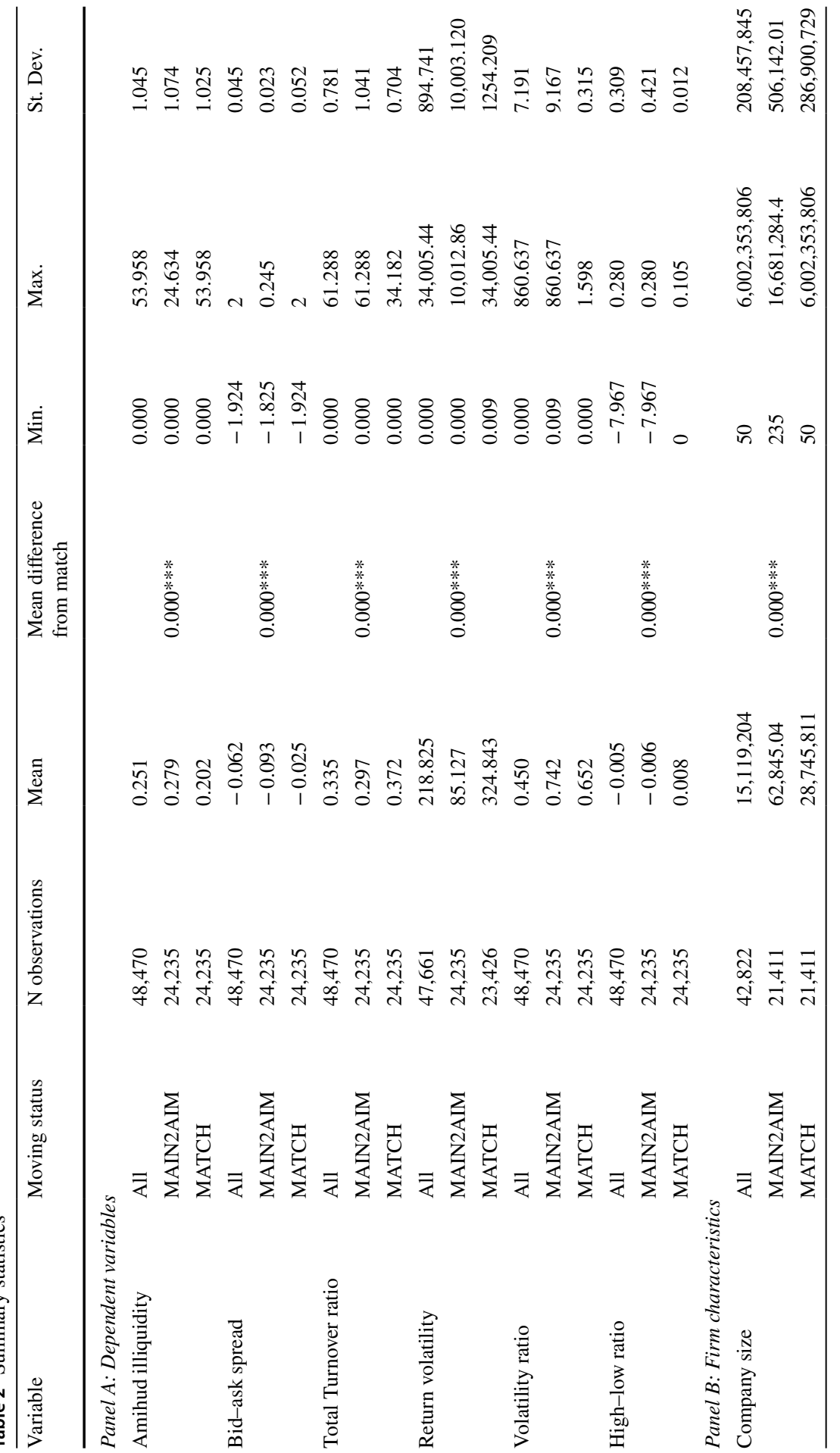




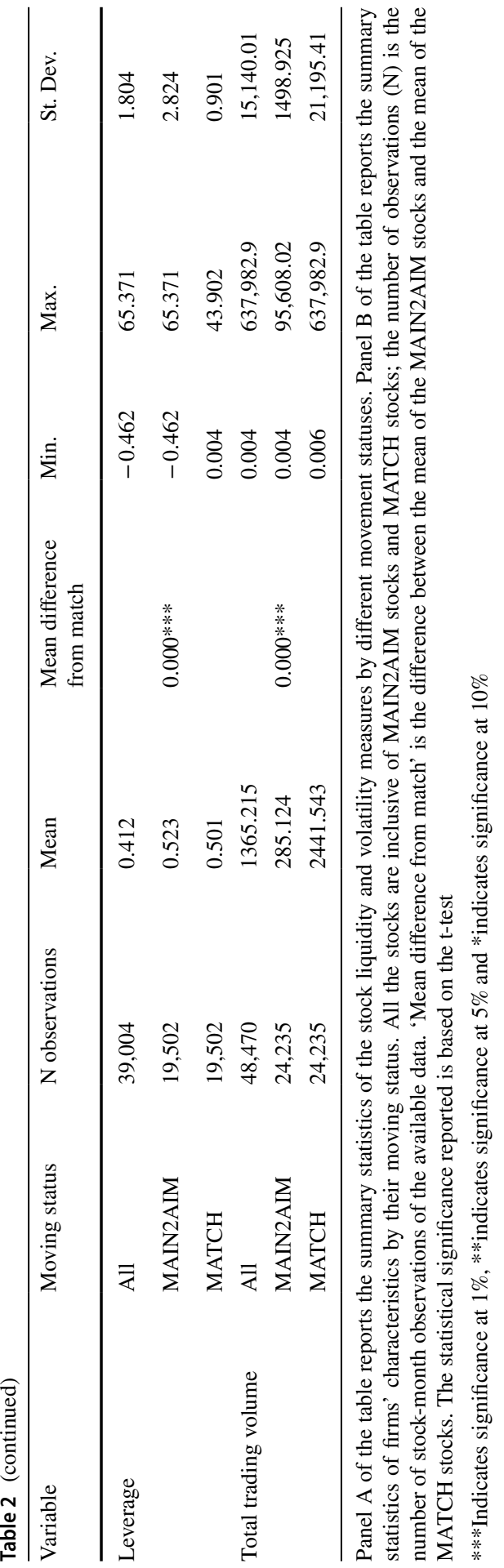


Table 3 Probit model

Probit

(1)

(2)

\begin{tabular}{lll}
\hline Company size & $-0.000^{* * *}(-20.14)$ & $-0.000^{* * *}(-15.01)$ \\
Leverage & $0.045^{* * *}(4.15)$ & $0.014 * * *(2.00)$ \\
IAS & $-0.596^{* * *}(-42.58)$ & $-0.615^{* * *}(-25.94)$ \\
Trading volume & $-0.000^{* * *}(-18.56)$ & $-0.000 * * *(-16.88)$ \\
Return volatility & $-0.000^{* * *}(-15.55)$ & \\
Volatility ratio & $0.854 * * *(0.013)$ & \\
High-low ratio & $-2.846^{* * *}(-7.014)$ & \\
Amihud & & $0.067 * * *(9.015)$ \\
Bid-ask spread & & $8.549 * * *(49.45)$ \\
Total turnover ratio & & $-0.045 * * *(-3.18)$ \\
Constant & $-0.110^{* * *}(-5.841)$ & $-0.417 * * *(-19.42)$ \\
N observations & 29,675 & 29,876 \\
Pseudo R-squared & 0.103 & 0.284 \\
\hline
\end{tabular}

The table reports the output from the probit model regression of the dependent variable, movement status, on the company size: Probability $\left(\mathrm{MS}_{\mathrm{i}, \mathrm{t}}\right)=\mathrm{f}\left(\omega \mathrm{M}_{\mathrm{i}, \mathrm{t}}\right)$, where $\mathrm{M}_{\mathrm{i}, \mathrm{t}}$ is the movement dummy variable that equals one if stock $\mathrm{i}$ is moved from the Main Market to the AIM and zero otherwise and $\mathrm{M}_{\mathrm{i}, \mathrm{t}}$ are the potential determinants of movement status. Model (1) is the probit model used as the first step of the Heckman procedure when the dependent variable of the second stage is any of the liquidity measures. Model (2) is the probit model used as the first step of the Heckman procedure when the dependent variable of the second stage is any of the volatility measures. The number $(\mathrm{N})$ of observations is the number of stock-month observations of the available data. The statistical significance reported is based on the t-test

$* * *$ Indicates significance at $1 \%, * *$ indicates significance at $5 \%$ and *indicates significance at $10 \%$. company size, company-level accounting practices, leverage and volume

ratio illustrates that the volatility of the matched firms is significantly higher than that of the MAIN2AIM firms.

The probability of a movement is estimated using the full sample of matched and moved companies before movement as a function of company-specific characteristics. Table 3 shows that, as predicted, companies that are smaller ${ }^{4}$ and have higher Amihud illiquidity and bid-ask spread and a lower total turnover ratio are more likely to move from the Main Market to the AIM. However, the coefficient of the volatility measures illustrates that companies with a lower return volatility and high-low ratio are more likely to move; companies with a higher volatility ratio have a higher probability of moving from the Main Market to the AIM.

\footnotetext{
${ }^{4}$ It should be noted that each moved company is paired with a Main Market company that is in the same industry group and has the nearest firm size (not a similar size) (following Errunza \& Miller, 2000).
} 


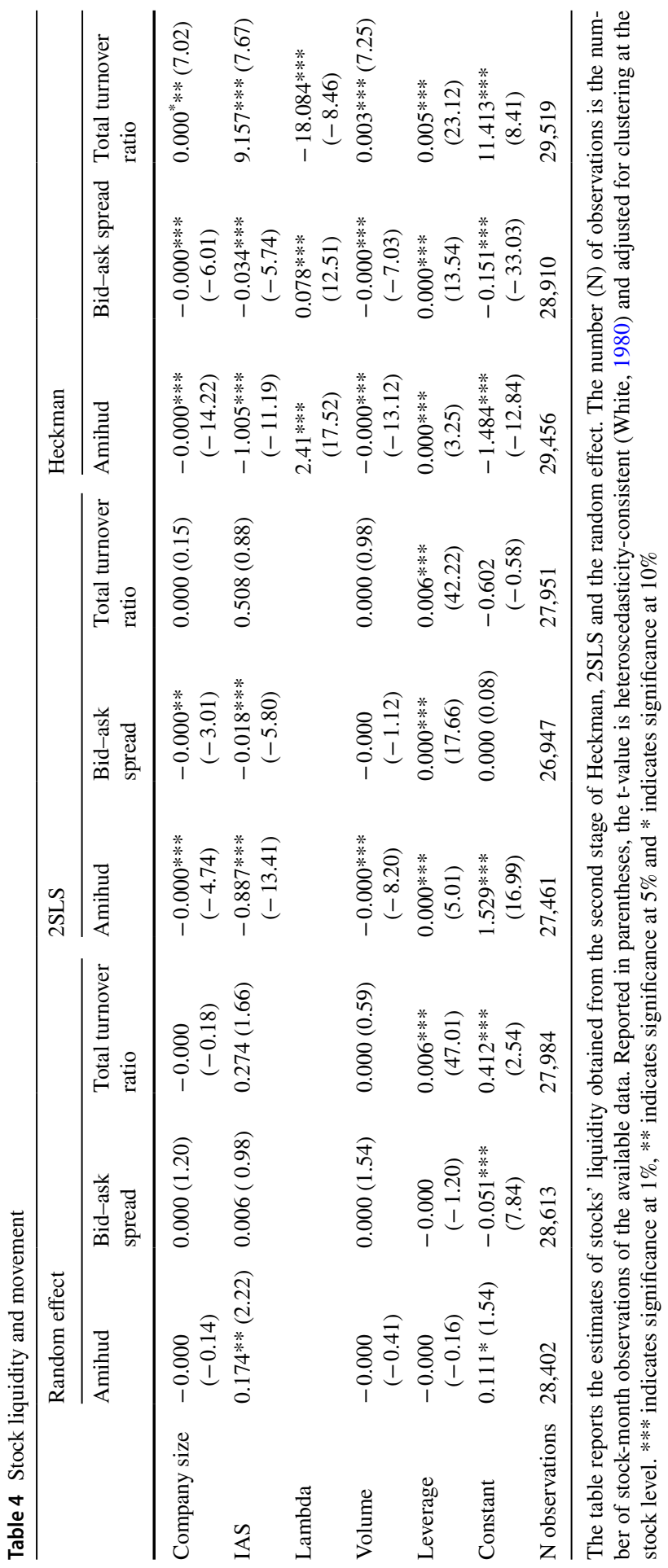


The results of the Heckman procedure and 2SLS are reported in Table 4. In addition, Table 4 compares the results of the self-selection models with random effects ${ }^{5}$.

\subsection{Liquidity}

Empirically, the results obtained in this study confirm the theory and show that trading activity is negatively correlated with Amihud illiquidity (Table 4). The positive and statistically significant relationship of the inverse Mills ratio and Amihud illiquidity explains that companies have a greater probability of moving from the Main Market to the AIM experience higher illiquidity (less liquidity) after the event date $^{6}$. Furthermore, the results show that the company size, international accounting standards and trading volume are negative and statistically significant determinants of the bid-ask spread. Similarly, this study shows that companies with higher leverage have a higher bid-ask spread due to the positive and significant correlation of leverage with the bid-ask spread in both the Heckman and the 2SLS model. Finally, the positive and statistically significant relationship of the inverse Mills ratio and the bid-ask spread shows that companies that have more probability to move from the Main Market to the AIM, face a higher bid-ask spread after the event date.

Moreover, the empirical results illustrate that the total turnover ratios have a positive relationship with company size, international accounting standards and trading volume. This relationship is statistically significant in the Heckman model. In addition, the significant and negative correlation of the inverse Mills ratio with the total turnover ratio shows that companies that are more likely to move from the Main Market to the AIM experience smaller total turnover ratio after the event date. To sum up, the findings on the change in stock liquidity after movement support hypothesis H1. More specifically, it is found that movement significantly increases stocks' transaction cost measured by the bid-ask spread and decreases stocks' turnover ratio.

\subsection{Volatility}

Table 5 reports a statistically insignificant positive relationship between the total turnover ratio and the return volatility. However, analysing the correlations of IAS, trading volume and leverage shows that companies with IAS, higher trading volume and lower leverage have higher return volatility. Moreover, the negative significant coefficient of lambda used in the Heckman model illustrates that companies that have less probability to move from the Main Market to the AIM, have higher return volatility after the event date. Therefore, this study empirically supports Leuz and Verrecchia (2000) and Brown and Hillegeist (2007), who mention that a higher

\footnotetext{
${ }^{5}$ Doidge et al. (2004) and Fernandes and Ferreira (2008) directly apply the random effect; however, in this study, the choice between the random effect and the fixed effect is made through the Hausman test.

6 The random effect shows the importance of considering self-selection bias. As the results show, the result of the random effect (which does not consider self-selection bias) is very different from the results of the Heckman and 2SLS models.
} 


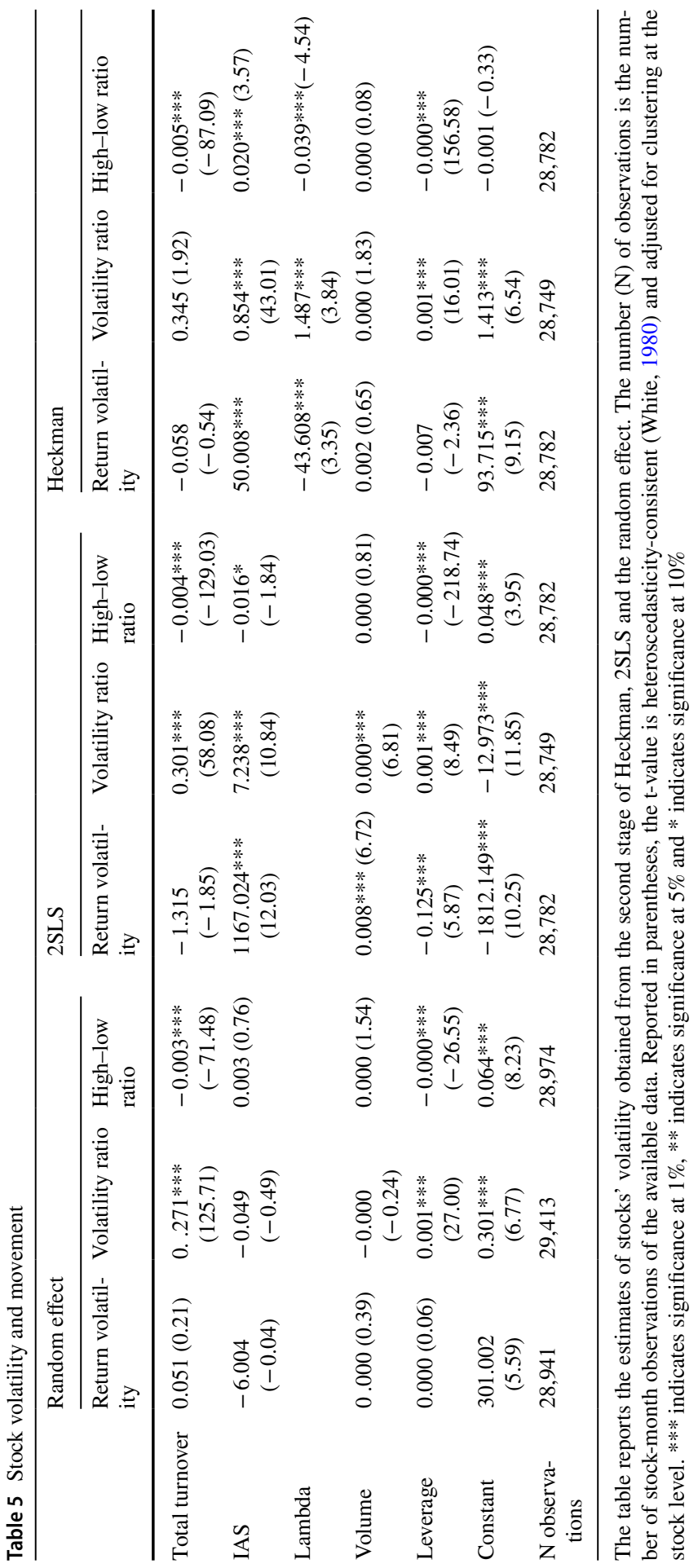


disclosure level will result in higher stock return volatility. Accordingly, companies that move from the Main Market with a higher disclosure level to the AIM with a lower disclosure level experience a decrease in their return volatility.

Analysing the relationship between the volatility ratio and total turnover ratio, the trading volume and the leverage shows that the volatility ratio is larger when the company has a larger turnover ratio, greater volume and more leverage based on both the Heckman and the 2SLS model. Also the coefficient of IAS illustrates a negative significant relationship in both Heckman and 2SLS model. The positive significant relationship of the inverse Mills ratio and the volatility ratio shows that the companies moved from the Main Market to the AIM experience higher volatility ratio after their movement.

The intraday volatility measured by the high-low ratio, which has a negative and significant coefficient estimate with lambda in the Heckman model, shows that the MAIN2AIM companies encountered a lower high-low ratio after their movement from the Main Market to the AIM. It can also be seen that the intraday volatility is negatively influenced by the total turnover ratio, IAS and trading volume. Analysing the correlations of IAS, trading volume and leverage shows that companies with international accounting standards, higher trading volume and lower leverage have higher high-low ratio. The decrease in the return volatility and high-low ratio after movement shows that the firm level and intra day volatility decrease after moving from the Main Market to the AIM. Hence, in line with the extensive empirical evidence in the literature (Chan \& Fong, 2000; Jones et al., 1994; Karpoff, 1987; Schwert, 1989), a smaller trading volume is found to be associated with lower volatility. Overall, according to the empirical evidence, Hypothesis H2, which states that movement from the Main Market to the AIM increases volatility, is not supported ${ }^{7}$. In order to reveal the dynamics, stock liquidity and volatility are examined around the movement dateas shown in Table 6. The findings of the analysis of the evolution of stock liquidity and volatility confirm and further extend the results from the cross-sectional analysis. Supportive of Hypothesis H1, moving from the Main Market to the AIM is found to be associated with lowered trading activities and raised transaction costs. However, the findings do not support Hypothesis $\mathrm{H} 2$ that the stock price of moved stocks is more volatile because of more risks originating from less disclosure in the AIM.

Table 7, reporting the mean of the Amihud illiquidity, bid-ask spread and total turnover ratios of the MATCH stocks, reveals that the Amihud illiquidity and bidask spread of these stocks decreased after their matched stock event date; it can also be seen that their total turnover ratio increased. On the other hand, the Amihud illiquidity, bid-ask spread and total turnover ratios of the MAIN2AIM stocks are more than one and statistically significant based on the t-test. This finding implies that the MAIN2AIM stocks faced higher Amihud illiquidity and bid-ask spread after their movement from the Main Market to the AIM; however, their total turnover ratio after their movement to the AIM improved. Table 7 also reveals the mean of

\footnotetext{
7 The increase in intraday volatility could be due to the structure and low trading of the AIM, which make the stock prices change more to attract investors.
} 


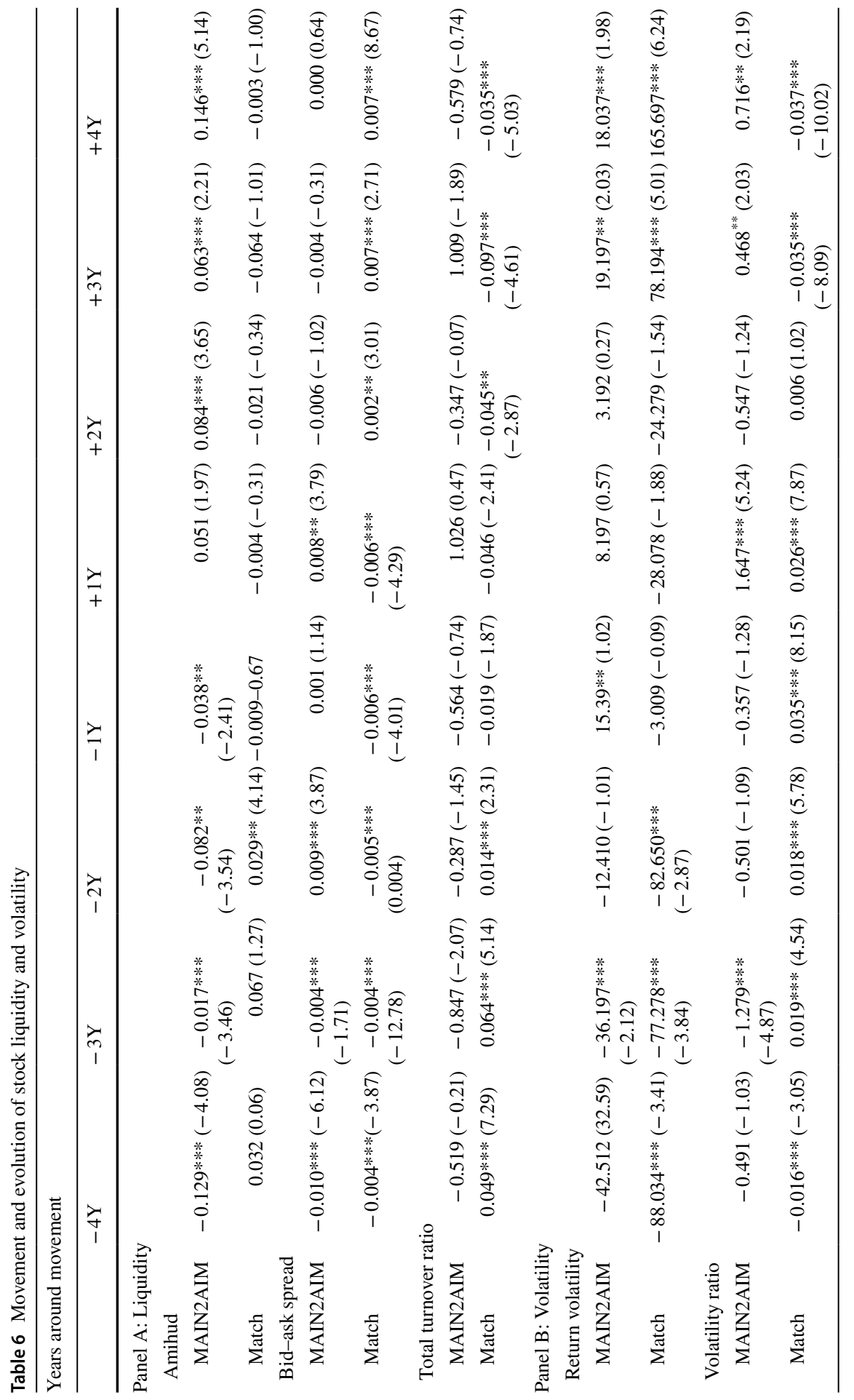




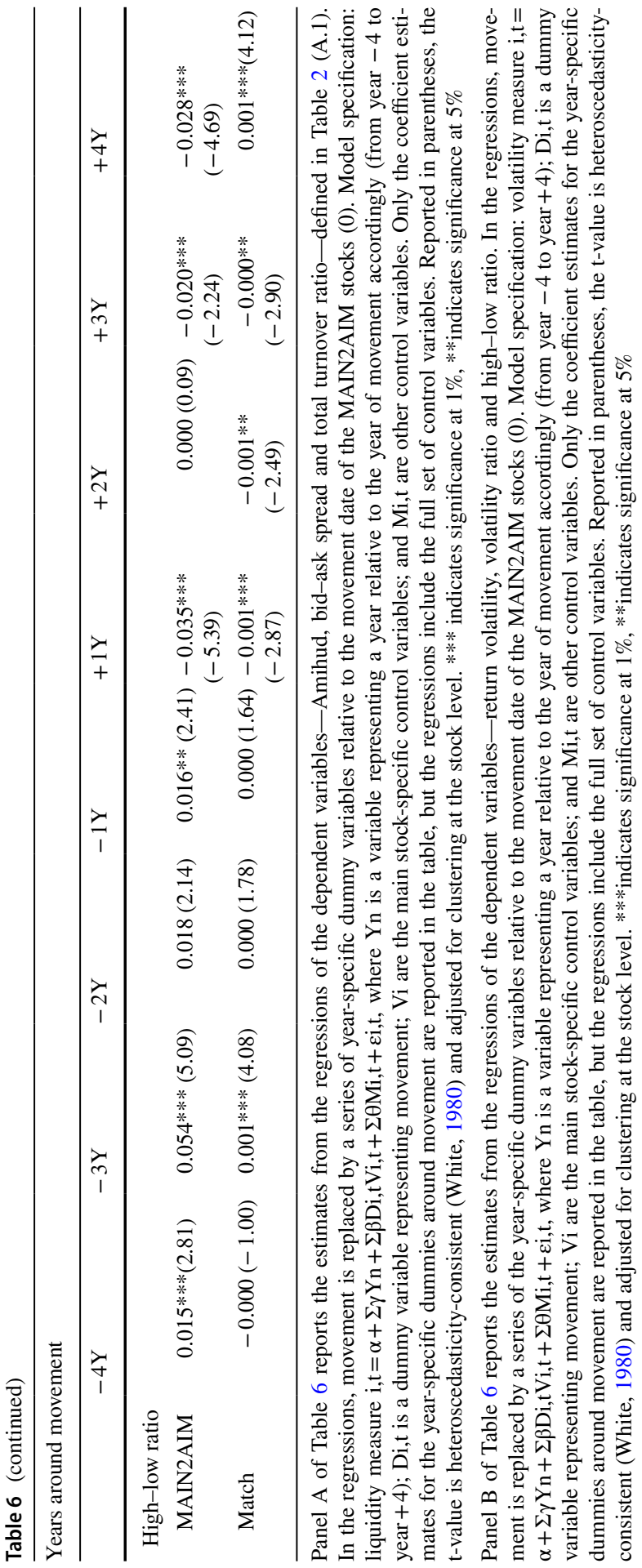


Table 7 Changes in stock liquidity, volatility and firm characteristics around movement: Univariate analysis

\begin{tabular}{|c|c|c|c|c|}
\hline \multirow[b]{2}{*}{ Variable } & \multirow[b]{2}{*}{ Movement status } & \multirow[b]{2}{*}{ Mean } & \multicolumn{2}{|c|}{$\begin{array}{l}\text { Mean difference } \\
\text { from } 1\end{array}$} \\
\hline & & & t-stats & $\operatorname{Pr}(\mathrm{t})$ \\
\hline \multicolumn{5}{|l|}{ Liquidity } \\
\hline \multirow[t]{2}{*}{ Amihud ratio } & MAIN2AIM & 3.659 & 6.128 & $<.0001$ \\
\hline & МATCH & 2.503 & 5.228 & $<.0001$ \\
\hline \multirow[t]{2}{*}{ Bid-ask spread ratio } & MAIN2AIM & 1.946 & 8.641 & $<.0001$ \\
\hline & MATCH & 0.854 & -3.120 & 0.0040 \\
\hline \multirow[t]{2}{*}{ Turnover ratio } & MAIN2AIM & 1.575 & 3.659 & 0.0003 \\
\hline & МATCH & 1.959 & 4.259 & $<.0001$ \\
\hline \multicolumn{5}{|l|}{ Volatility } \\
\hline \multirow[t]{2}{*}{ Return volatility ratio } & MAIN2AIM & 0.841 & -2.801 & 0.007 \\
\hline & МАTCH & 5.022 & 10.211 & $<.0001$ \\
\hline \multirow[t]{2}{*}{ Volatility ratio } & MAIN2AIM & 1.152 & 0.495 & 0.498 \\
\hline & MATCH & 1.027 & 0.132 & 0.603 \\
\hline \multirow[t]{2}{*}{ High-low ratio } & MAIN2AIM & 0.701 & -2.845 & 0.469 \\
\hline & MATCH & 1.540 & 1.878 & 0.106 \\
\hline
\end{tabular}

Panel A of the table reports the number of observations and the mean ratios of the stock liquidity and volatility measures by different movement statuses. The ratios are calculated as the average liquidity/volatility measure for the period of time after the movement date over the base liquidity/volatility measure, which is the average liquidity/volatility measure for the time before the movement date (at least 12 months). Additionally, the table reports the t-statistics and $\mathrm{p}$-value of the test of the difference in the means of the ratios from one (a ratio of one would indicate no change in the liquidity/volatility measure after movement)

the volatility ratios of the MAIN2AIM and MATCH stocks. It can be seen that the mean of the return volatility ratio of the MAIN2AIM stocks is less than one, which denotes a decrease in their return volatility after their movement to the AIM. On the other hand, the return volatility of the MATCH stocks shows that these stocks experienced higher return volatility after their matched stock event date. The mean comparison of the high-low ratio of the MAIN2AIM and MATCH stocks signifies that although MATCH stocks experienced an increase in their high-low ratio, consistent with the results reported in previous sections, MAIN2AIM stocks show lower highlow ratio after moving from the Main Market to the AIM. Finally, Table 7 shows no significant difference in the volatility ratio of both MAIN2AIM and MATCH stocks before and after the event date.

The univariate analysis reported in Table 7, compared the liquidity and volatility of both MAIN2AIM and MATCH stocks after event date with their own liquidity 


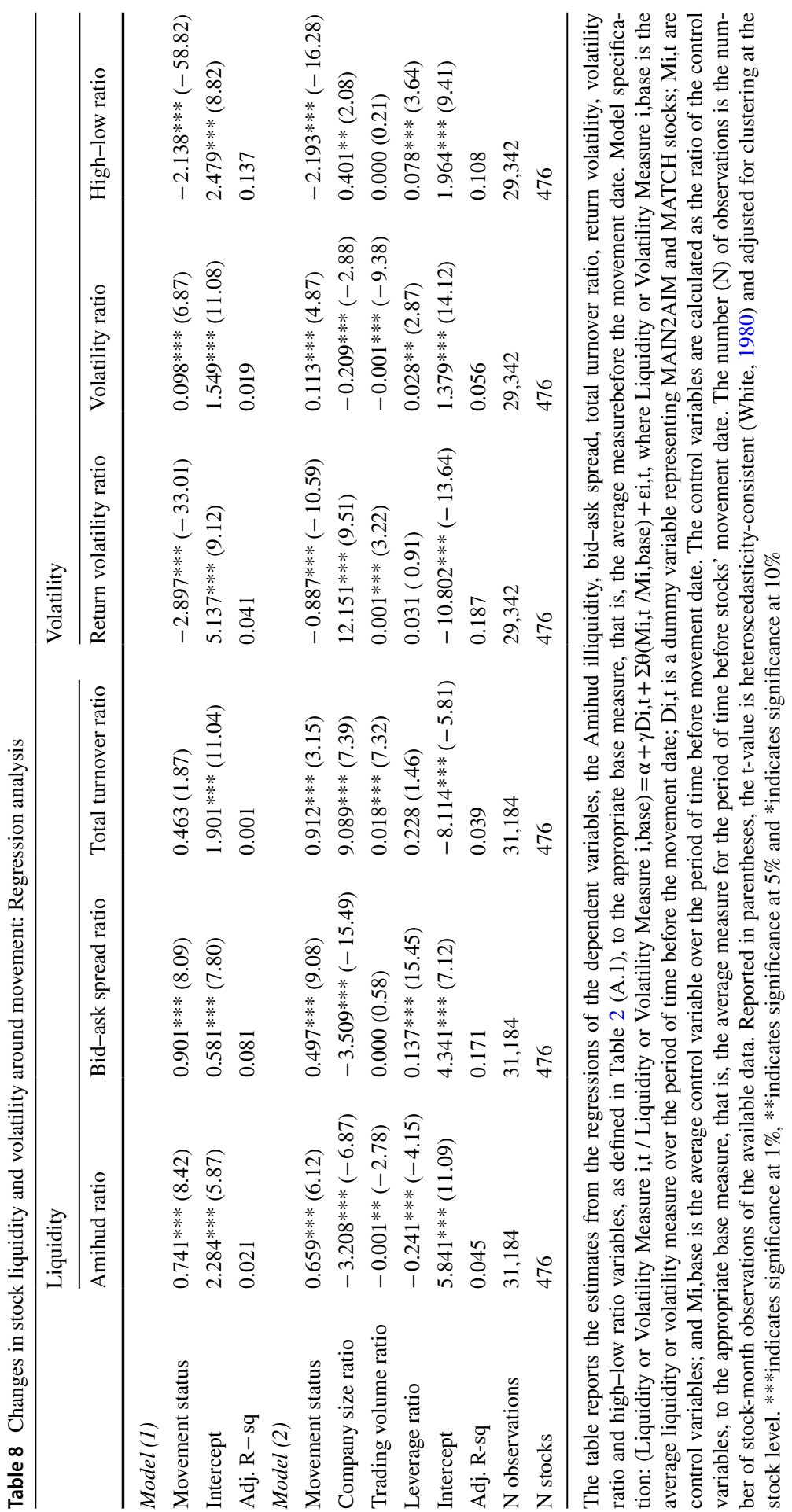


and volatility before event date by comparing just the mean of liquidity and volatility of before and after movement. The multivariate analysis reported in Table 8, is regressing the liquidity and volatility measure ratios by considering the dummy variables representing the movement status and the ratios of the control variables in order to determine the primary determinants of the changes in stock liquidity and volatility around the movement ${ }^{8}$. A stock movement to the AIM is associated with a significant increase in the Amihud illiquidity and bid-ask spread (Model (1), Table 8). Additionally, Model (2) controls for changes in the firm characteristics; as expected, a significant portion of the decrease in liquidity around movement can be explained by the decrease in the company size. Furthermore, part of the Amihud illiquidity and bid-ask spread increase can be explained by the lower stock trading volume and leverage after stocks' movement. In addition, the higher turnover ratio after movement might be because of better accessibility for investors who prefer to invest in illiquid stocks, which have a lower trading level.

Overall, the empirical results of the time-series analysis of the changes in stock liquidity after the event date support Hypothesis H1 that moving from the Main Market to the AIM worsens the liquidity of a stock as a result of a deterioration in the information environment.

Based on the regression output of Models (1) and (2) (Table 8), Model (1) illustrates that after the event date ${ }^{9}$, companies' movement status has a significant negative correlation with their return volatility and high-low ratio and a positive correlation with their volatility ratio. Based on Model (2) that additionally controls for changes in firm characteristics, an increase in the company size, trading volume and leverage after the event date increase return volatility and high-low ratio, which themselves have significant negative relationship with the movement status.

Moreover, Table 8 depicts that the volatility ratio after the event date has a significant positive relationship with the movement status, which means that moved companies have a higher volatility ratio than their matched companies. In addition, Model (2) of Table 8 explains that the volatility ratio has a significant negative correlation with the company size and trading volume and a significant positive correlation with the leverage ratio. The coefficients between the volatility ratio and the firm characteristics explain that although generally the volatility ratio increased after stocks' movement to the AIM, the companies with a smaller size, lower trading volume and higher leverage have a higher volatility ratio. Finally, in line with the theoretical expectations, the high-low ratio is negatively correlated with the movement status, which confirms that the stocks that moved from the Main Market to the AIM experienced a lower high-low ratio after their movement. Moreover, Model (2) of Table 8 clarifies the relationship between the high-low ratio and the firm characteristics.

Overall, the empirical results of the time-series analysis of the changes in stock volatility after moving from the Main Market to the AIM do not support Hypothesis

\footnotetext{
${ }^{8}$ The difference between this section and privous section is that privous section aim is to find out whether generally stock liquidity increased or decread after movement. However, this section is to identify the main determinants of the changes in stock liquidity and volatility around the event date.

9 'Event date' illustrates the date on which each MAIN2AIM company moved from the Main Market to the AIM and is used as the event date for the paired company in the MATCH group.
} 
$\mathrm{H} 2$, which relates to the increase in stock volatility after moving from the Main Market to the AIM due to the worsening of the stock's information environment.

\section{Conclusion}

A company's commitment to lower levels of information disclosure and scrutiny by market participants after moving from the Main Market to the AIM should increase the information asymmetry between managers and investors and between different groups of investors. The worse information environment of the stock after movement, in turn, should negatively affect stock liquidity and volatility. This study tests this proposition empirically by examining the changes in stocks' liquidity and return volatility after their movement from the Main Market to the AIM of the London Stock Exchange. The sample used in the study is a set of moved (MAIN2AIM) and matched (MATCH) companies; MAIN2AIM contains companies that moved from the Main Market to the AIM between January 1996 and December 2013. Each company in the MATCH group is a company that stayed in the Main Market and is paired with one company in the MAIN2AIM group.

Since movement to the AIM deteriorates stocks' information environment due to the lower level of information disclosure by companies as well as the production of less stock-specific information by a decreased number of investors, the MAIN2AIM stocks are expected to be less liquid and show more return volatility than the MATCH stocks. Three different methods are used to evaluate the relationship between the movement status and the stock liquidity and volatility. Firstly, the liquidity and volatility of the MAIN2AIM stocks are compared with the MATCH stocks, controlling for other determinants of stock liquidity and volatility in the cross-sectional analysis. Secondly, the evolution of the stock liquidity and volatility measures is tracked in the years around the movement date using the sample of MAIN2AIM stocks as well as the MATCH stocks. Thirdly, the stock liquidity and volatility after the movement date are evaluated against those of the same stocks for the period of time prior to the movement date using time-series analysis.

The empirical evidence shows that, compared with the stocks that stayed in the Main Market, the stocks that moved to the AIM have a lower level of trading activity, higher transaction costs and a less volatile stock return. After controlling for self-selection bias and other factors that potentially affect stock liquidity and return volatility, a movement from the Main Market to the AIM is associated with significant decrease in liquidity and increase in transaction costs measured by the Amihud illiquidity and bid-ask spread, along with a decrease in trading volumes and a significant reduction in return volatility. The changes in liquidity and volatility after movement are mainly explained by the increase in the transaction costs and decrease in the companies' trading activities after movement. The important finding is that the impact of movement on stock liquidity is sustained over time. More specifically, the observed increase in Amihud illiquidity and the bid-ask spread and the decrease in volatility are sustained for four years after moving from the Main Market to the AIM. The evidence from time-series analysis that investigates the changes in the 
liquidity and volatility of the MAIN2AIM stocks suggests that movement is associated with a significant decrease in stocks' liquidity. This is true even after controlling for the change in firm characteristics following the change in movement status.

Open Access This article is licensed under a Creative Commons Attribution 4.0 International License, which permits use, sharing, adaptation, distribution and reproduction in any medium or format, as long as you give appropriate credit to the original author(s) and the source, provide a link to the Creative Commons licence, and indicate if changes were made. The images or other third party material in this article are included in the article's Creative Commons licence, unless indicated otherwise in a credit line to the material. If material is not included in the article's Creative Commons licence and your intended use is not permitted by statutory regulation or exceeds the permitted use, you will need to obtain permission directly from the copyright holder. To view a copy of this licence, visit http://creativecommons.org/licen ses/by/4.0/.

\section{References}

Amihud, Y. (2002). Illiquidity and stock returns: Cross-section and time-series effects. Journal of Financial Markets, 5(1), 31-56.

Amihud, Y., \& Mendelson, H. (1986). Asset pricing and the bid-ask spread. Journal of Financial Economics, 17(2), 223-249.

Amihud, Y., \& Mendelson, H. (1995). Multimarket trading: A self-regulatory proposal. In R. A. Schwartz \& I. Walter (Eds.), Global equity markets: Technological, competitive, and regulatory challenges (pp. 342-351). Irwin.

Ang, A., Shtauber, A. A., \& Tetlock, P. C. (2013). Asset pricing in the dark: The cross-section of OTC stocks. Review of Financial Studies, 26(12), 2985-3028.

Aouadi, A., Arouri, M., \& Roubaud, D. (2018). Information demand and stock market liquidity: International evidence. Economic Modelling, 70, 194-202.

Atkins, A. B., \& Dyl, E. A. (1997). Transactions costs and holding periods for common stocks. Journal of Finance, 52, 309-325.

Babus, A., \& Kondor, P. (2018). Trading and information diffusion in over-the-counter markets. Econometrica, 86(5), 1727-1769.

Baiman, S., \& Verrecchia, R. E. (1996). The relation among capital markets, financial disclosure, production efficiency, and insider trading. Journal of Accounting Research, 34(1), 1.

Baker, H.K., Nofsinger, J.R., Weaver, D.G., (1999). International cross-listing and visibility, Workingv paper No. 99-01, NYSE.

Baker, H. K., Nofsinger, J. R., \& Weaver, D. G. (2002). International Cross Listing and Visibility. Journal of Financial and Quantitative Analysis, 37, 495-521.

Bamber, L. S., Barron, O. E., \& Stober, T. L. (1999). Differential interpretations and trading volume. Journal of Financial and Quantitative Analysis, 34(3), 369-386.

Bancel, F., \& Mittoo, U. R. (2009). Why do European firms go public? European Financial Management, 15(4), 844-884.

Barclay, M. J., Litzenberger, R. H., \& Warner, J. B. (1990). Private information, trading volume, and stock-return variances. Review of Financial Studies, 3(2), 233-253.

Barry, C. B., \& Brown, S. J. (1986). Limited information as a source of risk. Journal of Portfolio Management, 12(2), 66-72.

Bartram, S. M., Brown, G., \& Stulz, R. M. (2012). Why are US stocks more volatile? Journal of Finance, 67(4), 1329-1370.

Berkman, H., \& Nguyen, N. H. (2010). Domestic liquidity and cross-listing in the United States. Journal of Banking and Finance, 34(6), 1139-1151.

Blasco, N., \& Corredor, P. (2017). The information environment, informed trading, and volatility. Journal of Behavioral Finance, 18(2), 202-218.

Brockman, P., \& Yan, X. (2009). Block ownership and firm-specific information. Journal of Banking and Finance, 33, 308-316. 
Brown, S., \& Hillegeist, S. A. (2007). How disclosure quality affects the level of information asymmetry. Review of Accounting Studies, 12(2-3), 443-477.

Campbell, J. Y., \& Kyle, A. S. (1993). Smart money, noise trading and stock price behavior. Review of Economic Studies, 60(1), 1-34.

Campbell, K., \& Tabner, I. T. (2011). Bonding, firm value and liquidity: An analysis of migrations between the AIM and the official list of the london stock exchange. SSRN Electronic Journal. https://doi.org/10.2139/ssrn.1608403

Chan, K., \& Fong, W. (2000). Trade size, order imbalance, and the volatility-volume relation. Journal of Financial Economics, 57(2), 247-273.

Chan, K. C., Fong, W., Kho, B., \& Stulz, R. (1996). Information, trading and stock returns: Lessons from dually-listed securities. Journal of Banking and Finance, 20(7), 1161-1187.

Chipunza, K. J., \& McCullough, K. (2018). The impact of internationalisation on stock liquidity and volatility: Evidence from the Johannesburg stock exchange. Journal of Economic and Financial Sciences, 11(1), 1-11.

Chouinard, E. \& D'Souza, C. (2004). The rationale for cross-border listings. Bank of Canada Review. pp. 23-30.

Collin-Dufresne, P., \& Fos, V. (2016). Insider trading, stochastic liquidity, and equilibrium prices. Econometrica, 84(4), 1441-1475.

Dabhane, T., (2018). The impact of cross-listing on stock liquidity in the home market: Comparative study of Indian companies cross-listed in Us, Uk and Luxembourg (Doctoral dissertation, Auckland University of Technology).

Dang, V. A., Michayluk, D., \& Pham, T. P. (2018). The curious case of changes in trading dynamics: When firms switch from NYSE to NASDAQ. Journal of Financial Markets, 41, 17-35.

De Carvalho, A. G., \& Pennacchi, G. G. (2012). Can a stock exchange improve corporate behavior? Evidence from firms' migration to premium listings in Brazil. Journal of Corporate Finance, 18(4), 883-903.

De Long, J. B., Shleifer, A., Summers, L. H., \& Waldmann, R. J. (1990). Noise trader risk in financial markets. Journal of Political Economy, 98(4), 703-738.

Diamond, D. W., \& Verrecchia, R. E. (1991). Disclosure, liquidity, and the cost of capital. Journal of Finance, 46(4), 1325-1359.

Dodd, O., \& Gilbert, A. (2016). the impact of cross-listing on the home market's information environment and stock price efficiency. Financial Review, 51(3), 299-328.

Doidge, C., Karolyi, G. A., \& Stulz, R. M. (2004). Why are foreign firms listed in the US worth more? Journal of Financial Economics, 71(2), 205-238.

Domowitz, I., Glen, J., \& Madhavan, A. (1998). International cross-listing and order flow migration: Evidence from an emerging market. Journal of Finance, 53(6), 2001-2027.

Eleswarapu, V. R., \& Venkataraman, K. (2006). The impact of legal and political institutions on equity trading costs: A cross-country analysis. The Review of Financial Studies, 19(3), 1081-1111.

Errunza, V., \& Miller, D. P. (2000). Market segmentation and the cost of capital in international equity markets. Journal of Financial and Quantitative Analysis, 35, 577-600.

Fang, V. W., Noe, T. H., \& Tice, S. (2009). Stock market liquidity and firm value. Journal of Financial Economics, 94(1), 150-169.

Fernandes, N., \& Ferreira, M. A. (2008). Does international cross-listing improve the information environment? Journal of Financial Economics, 88(2), 216-244.

Foucault, T., \& Frésard, L. (2012). Cross-listing, investment sensitivity to stock price, and the learning hypothesis. The Review of Financial Studies, 25(11), 3305-3350.

Foerster, S. R., \& Karolyi, G. A. (2000). The long-run performance of global equity offerings. Journal of Financial and Quantitative Analysis, 35(4), 499-528.

Gerakos, J., Lang, M. H., \& Maffett, M. G. (2011). Listing choices and self-regulation: the experience of the AIM. Chicago Booth Research Paper No 11-04.

Glosten, L. R., \& Harris, L. E. (1988). Estimating the components of the bid/ask spread. Journal of Financial Economics, 21(1), 123-142.

Glosten, L. R., \& Milgrom, P. R. (1985). Bid, ask and transaction prices in a specialist market with heterogeneously informed traders. Journal of Financial Economics, 14(1), 71-100.

Gozzi, J. C., Levine, R., \& Schmukler, S. L. (2008). Internationalization and the evolution of corporate valuation. Journal of Financial Economics, 88(3), 607-632.

Garvey, R., \& Wu, F. (2009). Intraday time and order execution quality dimensions. Journal of Financial Markets, 12(2), 203-228. 
Gomes, N. G. I., Semuel, H., \& Devie, D. (2019). Intellectual capital disclosure, information asymmetry, cost of capital, and firm value: Empirical studies on indonesian manufacturers. Petra International Journal of Business Studies, 2(1), 27-35.

Gregoriou, A., Ioannidis, C., \& Skerratt, L. (2005). Information asymmetry and the bid-ask spread evidence from the UK. Journal of Business Finance and Accounting, 32(9-10), 1801-1826.

Hail, L., \& Leuz, C. (2009). Cost of capital effects and changes in growth expectations around US crosslistings. Journal of Financial Economics, 93(3), 428-454.

Hamet, J. (2002). Is off-board trading detrimental to market liquidity? Financial Review, 37(3), 385-402.

Hatrick, K., So, M. K., Chung, S. W., \& Deng, R. (2011). Dynamic relationship among intraday realized volatility, volume and number of trades. Asia-Pacific Financial Markets, 18(3), 291-317.

Healy, P. M., Hutton, A. P., \& Palepu, K. G. (1999). Stock performance and intermediation changes surrounding sustained increases in disclosure. Contemporary Accounting Research, 16(3), 485-520.

Heflin, F., \& Shaw, K. W. (2000). Blockholder ownership and market liquidity. Journal of Financial and Quantitative Analysis, 35(4), 621-633.

Heckman, J. (1979). Sample selection bias as a specification error. Econometrica, 47, 153-161.

Heston, S. L., Korajczyk, R. A., \& Sadka, R. (2010). Intraday patterns in the cross-section of stock returns. The Journal of Finance, 65(4), 1369-1407.

Hombach, K., \& Sellhorn, T. (2018). Firm value effects of targeted disclosure regulation: The role of reputational costs. SSRN Electronic Journal. https://doi.org/10.2139/ssrn.3204505

Howe, J. S., \& Madura, J. (1990). The impact of international listings on risk: Implications for capital market integration. Journal of Banking and Finance, 14(6), 1133-1142.

Howe, J. S., Madura, J., \& Tucker, A. L. (1993). International listings and risk. Journal of International Money and Finance, 12(1), 99-110.

Huang, Y., Elkinawy, S., \& Jain, P. K. (2013). Investor protection and cash holdings: Evidence from US cross-listing. Journal of Banking \& Finance, 37(3), 937-951.

Jain, P. K., \& Kim, J. (2006). Investor recognition, liquidity, and exchange listings in the reformed markets. Financial Management, 35(2), 21-42.

Jones, C. M., Kaul, G., \& Lipson, M. L. (1994). Information, trading, and volatility. Journal of Financial Economics, 36(1), 127-154.

Karpoff, J. M. (1987). The relation between price changes and trading volume: A survey. Journal of Financial and Quantitative Analysis, 22(01), 109-126.

Kedia, S., \& Panchapagesan, V. (2011). Why do only some Nasdaq firms switch to the NYSE? Evidence from corporate transactions. Journal of Financial Markets, 14(1), 109-126.

Kim, J., Kartsaklas, A., \& Karanasos, M. (2005). The volume-volatility relationship and the opening of the Korean stock market to foreign investors after the financial turmoil in 1997. Asia-Pacific Financial Markets, 12(3), 245-271.

Krishnamurti, C., Šević, A., \& Šević, Ž. (2005). Voluntary disclosure, transparency, and market quality: Evidence from emerging market ADRs. Journal of Multinational Financial Management, 15(4), 435-454.

Kryzanowski, L., \& Lazrak, S. (2009). Liquidity minimization and cross-listing choice: Evidence based on Canadian shares cross-listed on US venues. Journal of International Financial Markets, Institutions and Money, 19(3), 550-564.

Kyle, A. S. (1985). Continuous auctions and insider trading. Econometrica: Journal of the Econometric Society, 53(6), 1315-1335.

Lambert, R., Leuz, C., \& Verrecchia, R. E. (2007). Accounting information, disclosure, and the cost of capital. Journal of Accounting Research, 45(2), 385-420.

Lang, M., \& Lundholm, R. (1993). Cross-sectional determinants of analyst ratings of corporate disclosures. Journal of Accounting Research, 31(2), 246-271.

Lesmond, D. A. (2005). Liquidity of emerging markets. Journal of Financial Economics, 77(2), 411-452.

Leuz, C., \& Verrecchia, R. E. (2000). The economic consequences of increased disclosure (digest summary). Journal of Accounting Research, 38, 91-124.

Lowengrub, P., \& Melvin, M. (2002). Before and after international cross-listing: An intraday examination of volume and volatility. Journal of International Financial Markets, Institutions and Money, 12(2), 139-155.

Ma, R., Anderson, H. D., \& Marshall, B. R. (2016). International stock market liquidity: A review. Managerial Finance. 
Mansaku, I., Mansaku, S., \& Tampakoudis, I. (2017). An empirical comparison of the major stock exchanges: NYSE, NASDAQ and LSE in Perspective. Academic Journal of Interdisciplinary Studies, 5(3S1), 406.

Menkveld, A. J. (2008). Splitting orders in overlapping markets: A study of cross-listed stocks. Journal of Financial Intermediation, 17(2), 145-174.

Menyah, K., \& Paudyal, K. (2000). The Components of bid-ask spreads on the London stock exchange. Journal of Banking and Finance, 24(11), 1767-1785.

Merton, R. C. (1987). A simple model of capital market equilibrium with incomplete information. Journal of Finance, 42(3), 483-510.

Mortazian, M., Tabaghdehi, S. A. H., \& Mase, B. (2019). Large shareholding and firm value in the alternative investment market (AIM). Asia-Pacific Financial Markets, 26(2), 229-252.

Noronha, G. M., Sarin, A., \& Saudagaran, S. M. (1996). Testing for micro-structure effects of international dual listings using intraday data. Journal of Banking and Finance, 20(6), 965-983.

Papaioannou, G. J., Travlos, N. G., \& Viswanathan, K. G. (2009). Visibility effects and timing in stock listing changes: Evidence from operating performance. The Quarterly Review of Economics and Finance, 49(2), 357-377.

Reinganum, M. R. (1990). Market microstructure and asset pricing: An empirical investigation of NYSE and NASDAQ securities. Journal of Financial Economics, 28(1), 127-147.

Rodrigues, S.D.S. and Galdi, F.C., (2017). Investor relations and information asymmetry. Revista Contabilidade and Finanças, (AHEAD), pp.0-0.

Roll, R. (1984). A simple implicit measure of the effective bid-ask spread in an efficient market. The Journal of Finance, 39(4), 1127-1139.

Schwert, G. W. (1989). Why does stock market volatility change over time? The Journal of Finance, 44(5), 1115-1153

Silva, A. C., \& Chávez, G. A. (2008). Cross-listing and liquidity in emerging market stocks. Journal of Banking and Finance, 32(3), 420-433.

Stoll, H. R. (1978). The supply of dealer services in securities markets. Journal of Finance, 33(4), 1133-1151

Stoll, H. R. (2001). Market fragmentation. Financial Analysts Journal, 57(4), 16-20.

Tandon, K., \& Webb, G. P. (2001). Evidence and implications of increases in trading volume around exchange listings. Financial Review, 36(2), 21-44.

Tse, Y., \& Devos, E. (2004). Trading costs, investor recognition and market response: An analysis of firms that move from the Amex (Nasdaq) to Nasdaq (Amex). Journal of Banking and Finance, 28(1), 63-83.

Wang, J. (1993). A model of intertemporal asset prices under asymmetric information. Review of Economic Studies, 60(2), 249-282.

Welker, M. (1995). Disclosure policy, information asymmetry, and liquidity in equity markets. Contemporary Accounting Research, 11(2), 801-827.

White, H. (1980). A heteroskedasticity-consistent covariance matrix estimator and a direct test for heteroskedasticity. Econometrica, 48(4), 817-838.

Publisher's Note Springer Nature remains neutral with regard to jurisdictional claims in published maps and institutional affiliations. 